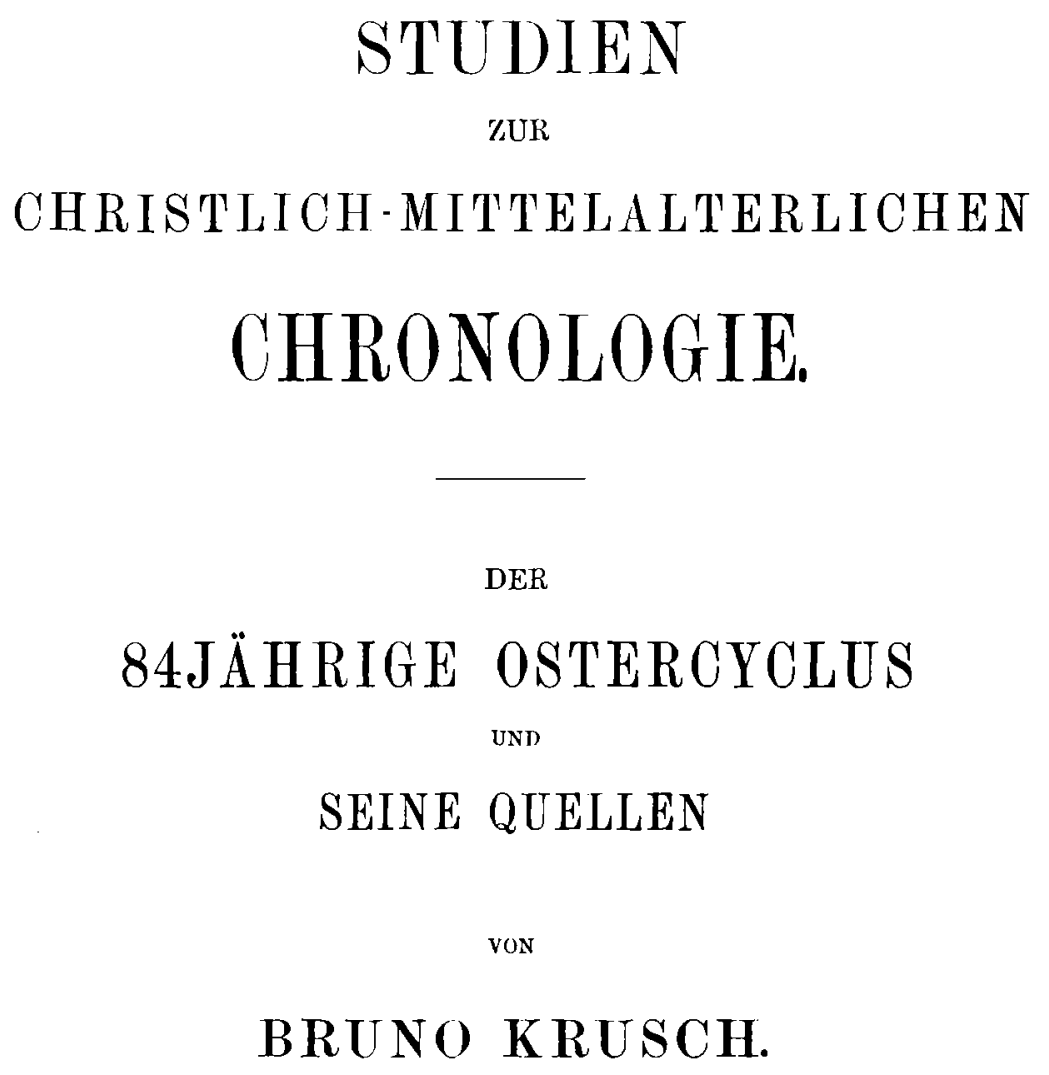

\title{
84JÄHRIGE OSTERCYCLUS
}

UND

SEINE QUELLEN

BRUNO KRUSCH.

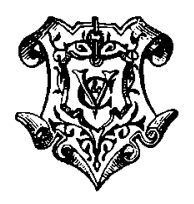

LEIPZIG,

VERLAG VON VEIT \& COMP.

1880. 
Druck von Motzger \& Wittig in Leipzig. 
HERRN PROFESSOR

\section{DR. WILHELM ARNDT}

IN DANKBARER VEREHRUNG

GEWIDMET. 
